\title{
Mother's Bag of Tricks: Irish Folklore, Tradition and Identity in John McGahern's Fiction
}

\author{
Anne'in Hileli Oyun Torbası: John McGahern Edebiyatında İrlanda Folkloru, \\ Gelenek ve Kimlik
}

\section{Dana Radler}

\begin{abstract}
Alienation makes the heroes in John McGahern's stories behave or appear like uncontrolled, wild and fearful creatures, anticipating a peril but unable to detect a precise danger and the way to counteract its impact. The demarcation between the safe and unsafe territory is even more difficult in circumstances related to death and funerals, as characters are transposed into a symbolically-built space where images, sounds, colours, and domestic totems help or restrain them, linking the visible to the subconscious. Diverse motifs from the animal, vegetal or human realms, are accompanied by a panoply of stylistic means employed to take the readership into a genuine Irish setting in which animal representations often mirror feelings of numerous humans, from hope to despair, or frailty to rigidity. This paper aims to explore the way in which folklore-extracted elements shape Irish identity and recurrently emerge in McGahern's literary works, the result being a unique mixture of imagery and personal memories implanted in both content and narrative.
\end{abstract}

Keywords: John McGahern, Irish tale, alienation, nature, orality

\footnotetext{
* Assist Lecturer, Bucharest University of Economic Studies, Faculty of Economic International Relations, Department of Modern Languages \& Business Communication, Bucharest, Romania, daniela.radler@rei.ase.ro

* Yrd. Doç. Bükreș Üniversitesi, Ekonomi Araștırmaları, Uluslararası Ekonomik İlișkiler Fakültesi, Modern Diller ve İș Ticareti İletișim Bölümü, Bükreș, Romanya, daniela.rader@rei.ase.ro
} 


\section{Özet}

Yabancılaşma, John McGahern'in öykülerinde, onun kahramanlarının, tıpkı kontrol edilemeyen, vahşi ve korkunç yaratıklar gibi davranmalarına ya da öyle görünmelerine yolaçar; bir tehlikenin gelmekte olduğunun sezinlerler, fakat tam olarak tehlikeyi göremezler ve yaratacağ 1 etkiyi nasıl tesirsiz hale getireceklerini öngöremezler. Ölüm ve cenazeye bağlı durumlarda, güvenli ve güvensiz ortamlar arasındaki sınırın belirlenmesi oldukça zordur; karakterler, bir yandan sembollerden kurulmuş bir uzam alanına doğru kaydırılırken, görüneni bilinçaltına bağlayan imgeler, sesler, renkler ve ev totemleri onlara yardımcı olurlar ya da onları sınırlandırırlar. Okurları, özgün bir İrlanda atmosferine alıp götürmek amacıyla, bitki, insan ve hayvanlar aleminden alınan çeşitli motifler, muhteşem bir üslup düzeninin kullanımına eşlik ederler; bu özgün İrlanda ortamında, hayvan simgeleri, çoğunlukla, umuttan ümitsizliğe, ya da kırılganlıktan acımasız bir sertliğe doğru uzanan, insana özgü, sayısız duyguları yansıtırlar. Bu makale, İrlanda kimliğine biçim veren folklordan çıkartılıp alınan ögeleri keşfetmeyi ve McGahern' in edebi eserlerinde nasıl, hangi yollarla ortaya çıktıklarını irdelemeyi amaçlamaktadır; sonuç, hem içeriğe, hem de anlatıma yerleştirilmiş kişisel anılardan ve imgelerden oluşan emsalsiz bir karışımdır.

Anahtar Sözcükler: John McGahern, İrlanda hikâyesi, yabancılaşma, doğa, sözel anlatim.

\section{Introduction: Irish folklore, tradition and identity}

"I write because I need to write. I write to see. Through words I see" declares John McGahern in "Playing with Words", included in the Love of the World collection of essays (2009: p. 9). Acclaimed for his unique prose, often realist and sharp, embracing people with all their qualities and weaknesses, McGahern's stories continue to be read by various generations across several continents. The vision John McGahern refers to in the quote above is both an individual gift and a heritage passed on to many generations before him; he inherited this gift from his mother and shared it generously in the format of novels and short stories. This paper aims to explore the way in which folklore shapes Irish identity in fiction and emerges recurrently in McGahern's literary works, the result being a unique mixture of imagery and personal memories implanted in both content and narrative.

This analysis can start with the example of using different titles for his volumes in their editions in Ireland/Britain versus the United States, which illustrates his decision to opt for a certain title and launch it under an auspicious sign, following the Irish traditions of good omens. His last volume, entitled simply Memoir, appeared in America under the title All Will Be Well, and this choice certainly reflects the author's intention to resonate with his audience, but it also relates to a short passage coming from T.S. Eliot, as suggested by Denis Donoghue who advocates for the idea of purification out of a creative yet difficult process:

And well shall be well and

All manner of thing shall be well

By the purification of the motive

In the ground of our beseeching. ${ }^{1}$

McGahern's force comes from a long orality marking the discourse of locals 8 long 
before him; it often involves a mild tone of sarcasm, since comments: upon one's fate connect with the hint of personal thinking turning into a symbolic paradox. This is the case of a middle-aged, thoroughly disappointed local teacher who is finally happy for the day to have come to an end, when the arms of the clock reach three oclock, and his expressed thoughts highly contrast his inner monologue. The end of his indirect speech triggers a perceivable silent roar of laughter to his own existential fiasco: "I hear their whoops of joy go down the road, and I linger over the locking up. I am always happy at this hour. It's as if the chains of the day were worth wearing to feel them drop away. I feel born again as I start to pedal towards the town. How, how, though, can a man be born again when he is old? Can he enter a second time his mother bag's of tricks? I laugh at last" (1992: p. 111).

Irony, paradox and humour are carefully manoeuvred by McGahern: in his informative study, Diarmuid Ó Giolláin observes two remarkable characteristics of Irish traditions: firstly, that this area holds simultaneously a certain "homeliness and vagueness" (O Giollain 2000: p. 1) unlike well-established scholastic areas, such as anthropology or sociology, and secondly, that, despite the above, it continues to manifest "an immediate emotional resonance" due to its "aura" (O Giollain 2000: p. 2). Such a force is certainly connected to the history of Ireland, and, more recently, with the wave of a rather "nationalist" reaction to the English majority and the expression of local history and identity.

After the Great Famine, he observes that " $\mathrm{t}] \mathrm{he}$ loss of the language involved the acquisition of English and a greater likelihood of literacy, with the direct loss of Gaelic oral traditions, traditional knowledge in general, and the attendant opening to modern ideas" (O Giollain 2000: p. 16). Yet, before, that, looking in retrospect at the long series of centuries in which Celtic rites co-existed with Christian ceremonials, until the early 19th century, a practically unparalleled experience by other European cultures, Vito Carassi explains such a phenomenon by an internal cultural characteristic which "goes beyond mere perception, to an attraction of that unreachable world lying well beyond everyday reality, to the near devaluation of pure corporeity in the name of a striving for the absolute, the infinite." (2012: p. 29). This very unique aspect enabled the Irish culture to manifest its "visionary character and imaginative power" ( p. 29).

Once the Irish society started to modernize in the 19th century, those traditions underwent difficult times, and were later exploited in fiction as well, mainly to present familiar heroic features and heroes. But, at the same time, writers felt an increasing need to preserve their cultural heritage not only along a Romantic trend, but in a more realist manner, sometimes incorporating subtle elements into their own narrative, in a rather unconscious way. As Marguerite Quintelli-Neary explains in her study devoted to folklore and their representations in the modern Irish novel; the diverse tradition of storytelling was performed by either an ollamh, a fili, loidhe or seanachie 2 whose mission was taken over by modern narrators: "The modern novelist could serve as any one or a combination of several of these storytellers, alternately recording his literary, fictional tale, reciting genealogy in parodic fashion, and constructing a wandering hero tale, as Joyce does in Ullysses" (1997: p. 5). John McGahern assumes the role of an artist, and places his prose 
in the line of storytelling and Anglo-Irish literature, yet he does it by weaving images and stylistic means from the old Gaelic tradition, a mix of vegetal and animal representations, human figures and diverse scenes: family and rural events, love, illness or dying, or rites of passage, both to adulthood or the otherworld. By doing, that, the novelist becomes a creator able to give eternal life to dying traditions and an ancient way of living which was to disappear in the post-war agricultural and industrial transformations, and his ability to capture it is brightly suggested by Maria Tymoczko and Colin Ireland: "Whenever a world is about to disappear, a poet emerges to utter it, and through that poet it achieves a comprehensive articulation. If that world has been self-enclosed or cut off by the facts of nature from the wider society, then it often reaches such a point of artistic refinement through its own inner resources" (2003: p. 195).

\section{Fantasies of vegetal and animal representations}

McGahern's stories abound in representations of rural landscapes, bogs, hills and waters surrounding individuals in their everyday activities. There is a whole range of semantic operators associated to rural life, for instance: bees and hives in "The Conversion of William Kirkwood" (The Collected Stories 1992: p. 331-349), donkeys, high hedges, thistles and nettles, ash, oak or sycamore trees, pike, perch and eels, pools, meadows, small lakes, moonlight, green lanes, potato shoots, sheds full of pigs and cattle, ploughs harrows, turf shed, and other references to the space around the barracks where he spent his childhood and early years (Memoir 2005). They are a constitutive part of the life of his characters, both victims and heroes, both males and females, and they combine their experiences in joyful, routine or sad stories, as life in the early decades of the 1940s and 1950s used to be.

Most often they are presented in what stands for a blurred area between reality and dream. Characters often seem to be so intensely absorbed by their inner monologues, that the natural surrounding seems to quietly enhance their pensive mood, or are occasionally helped to overcome difficult emotional moments by ignoring the brutal side of life. The writer's innate ability to appeal to the healing powers of nature, or a silent resonance with all its beings is certainly derived from what has been coined as the 'fantasy' incorporated in artistic creation: "the unreal becomes the real in the context of the narrative" and "is often perceived as having the significance of dreams" (Harris 2008: p. 2). Through the voice of characters or of the narrator, McGahern comes back to this theme over and over: "The night seemed so full of serenity that it brought the very ache of longing for all of life to reflect its moonlit calm, but I knew it too well neither was nor could be. It was a dream of death" (McGahern 1992: p. 224); "They could in time even take care over other farms, a dream he had once had about his eldest son: together they could take over everything" (McGahern 1991: p. 108) or "I wanted to be alone, to go over the night, to try to see clearly, which only meant turning again and again in the wheel of dreaming" (McGahern 1985: p. 94).

The same kind of blurred space mixing reality with dreams arises in his reflection about the years spent in Trinity College Dublin, and the ongoing reading and re-reading of John Butler Yeats' correspondence: "Sleep is dreaming away from the facts and wakefulness is 
dreaming in close contact with the facts, and since facts excite our dreams and feed them we get as close as possible to the facts if we have the cunning and the genius of poignant feeling..." (McGahern 2009b: p. 39). That vision is explained by an understanding of a state of mind: the pleasure to look out of the window, at the busy people crossing in front of the windows, the amiable conversation with cleaners, porters and other support staff, but also to "live in the quiet in the very heart of Dublin" (McGahern 2009b: p. 38) as in a safe cocoon far from the restaurants, bars and outside enjoyable areas. McGahern the writer is always interested in the people he meets, he enjoys casual conversation, new points of view, words or idioms he hadn't met before, and he enjoys friendly people as much as he looks critically yet humorously at those rallying against him occasionally, conformists and rather unsociable individuals.

The reality-like-a-dream vision is certainly intensified by the use of vegetal constituents pointing to supply, transfer, or skin and hair as suggested by Ella Sharpe Freeman: "Trees in dreams are objects on to which personal attributes are often transferred. 'Bay trees' and 'beech trees' I have found selected because the person whom the tree signified was once seen on a seashore. 'Yew' trees I have found indicated the transference on to the analyst of an unconscious imago (you). A 'pine' tree I have found indicating an unconscious longing for the person the tree represented, a 'birch tree' the representation of a punishing parental image (...)" (Sharpe Freeman 1988: p. 18).

Birch trees appear occasionally in other stories or novels as well, mainly used in descriptions of Irish meadows and farm work: "... long acres of sedge as pale as wheat and taller, the stunted sally and birch trees rising bright as green flowers" (McGahern 2009c: p. 140); "I grew to love Gloria Bog, its acres of pale sedge, an inland sea broken by stunted birch trees, the trees like green flowers, the dark gashes of the turf banks, the soft light on the heather" (McGahern 2005: p. 162-3); “...the acres of pale sedge of Gloria Bog, which ran like an inland sea until it met the blue of the lower slopes of the mountains where his life began, the stunted birch trees like small green flowers in the wilderness of bog" (McGahern 2002: p. 41); "Mention of suicide suddenly brought back the early days of their relationships in that country of snow and birch trees and white houses..." (McGahern 1992: p. 80). In "The Wine Breadth" (The Collected Stories) beech trees are associated with unnoticed changes by the priest who has a flashback of Michael Bruen's death, a familiar local. As Sharpe noted earlier, beeches provide the framework for memories about someone being on the seashore, and this is revealed in the story by multiple references to sea and water both in concrete and abstract constructions: "feeling a washed-out parody of a child or old man on what was after all nothing more than a poor errand" (McGahern 1992: p. 179), "the watery light was shining down the alder rows to fall on the white chips of the beechwood strewn all about Gillespie" (1992: 179) "his life was already another such watermark of memory", and "he saw himself as an old man children were helping down to the shore" (1992: p. 182). The final reference to sailing puts his own destiny under the question mark, as the question in the text implies the answer: "Was his life the calm vessel it had seemed, dully setting out and returning from the fishing grounds? Or had he been always what he seemed now?" (1992: p. 186).

This story also uses references to the vegetal world to bring forward literary opinions 
expressed indirectly by the author. The first, as Bertrand Cardin notes, is a hint to a poem by Yeats, through the very title of the story, being "an important allusion to "All Souls" Night", a poem Yeats wrote in 1920, which contains the following lines: "A ghost may come/ For it is a ghost's right,/ His element is so fine/ Being sharpened by his death,/ To drink from the wine-breath/While our gross palates drink from the whole wine"' (2009b: p. 2). The second is a rather judgemental opinion related to literary clichés spread by nationalist writers in the mid-twentieth century voiced by a McGahern's character: "And no doubt, the little rose of Scotland, [is] sharp and sweet and breaks the heart" (p. 186) says Peter Joyce to the priest in this story, criticising the popular yet low-style nationalistic discourse and symbolism. The reference to the rose is an indirect critique to literary clichés used by Hugh MacDiarmid in his poem published in 1931: "The rose of all the world is not for me./ I want for my part / Only the white rose of Scotland / That smells sharp and sweet - and breaks the heart." 3 To expand on this critical interpretation further, the title of the story hints to the drinking habit of the reverend and him enjoying it with Michael Bruen, his remembered friend, but the mention of drinking may act as a secondary critical source to MacDiarmid himself when we learn from recent sources that he was noted to share it: "Spies had infiltrated an extremist grouping of Scottish nationalists, and found that while the inner circle, referred to as "Croileagan na h Alba", was being provided with money to keep it alive, MacDiarmid would not be admitted because he was believed to be "dishonest and fond of drink." 4 As often the case in McGahern's stories, elements extracted from reality or emerging from friends, rumours or publications of the time may have influenced the author to place such a hint, hardly noticeable to his modern readership, but preserving the ample potential of satire to the connoisseurs.

The imagery derived from tales is highlighted by numerous representations of water, floods, rivers, seas and creatures associated with the water-life. A useful framework for this analysis is provided by the very title of McGahern's collection of short stories: Creatures of the Earth. The fantasy relies both in content and the narrative, as the novelist confesses simply in his introduction, pointing out their emergence from deeply-stored images into their capturing in fiction, implying change, move and relocation: "These stories grew in the mind and in the many workings of the material, but often began from as little as the sound of a chainsaw working in the evening, an overhead conversation about the price of cattle, thistledown floating by the open doors of bars on Grafton street on a warm autumn day, an old watch spilling out of a sheet where it had been hidden and forgotten about for years (...). Unless they were reinvented, re-imagined and somehow dislocated from their origins, they never seem to work. The imagination demands that life be told slant because of its need of distance" (2009a: p. vii).

The understanding of fiction complexly connected to the harsh reality of life needs to be done in conjunction with the practice of old traditions in Ireland, which has to take into account old occupations, one of them, fishing, being recurrently represented in McGahern's prose. Estyn Evans notes minutely various fishing habits, including tools and manner of killing: "Bobbing for eels with a ball of worms attached to a string is practised on dark stormy nights and on the River Bann vicious-looking eel-rake is used to jab 
among the river weeds. (...) Salmon are also strokehauled with naked hooks, and gaffed when within reach of the river banks. Trout taken not only by ginling (tickling) but also with a "dull" or horsehair noose" (Evans 2000: p. 243).

In "Korea", first published in the 1970 Nightlines volume of short stories, the young male hero describes a fishing expedition with his father, and his gestures, though casual, hint to something dark going to take place; in this case, fishing and the image of rapacious river creatures suggests a wider, premonitory background, once we learn that the young man's father discusses potential financial gains over his son's departure to America. This premonition links the representation of the eel with the very meaning of the word and its symbolism: "eascann" stands for the Gaelic "word for eels" and the old connotation is equally negative: "The eel has a generally negative image in Irish folklore, perhaps related to its superficial resemblance to a snake" (Tsukamoto and Kuroki 2014: p. 14) To this end, Linda Collinge and Emanuel Vernadakis point out that fishing eels was spread in the area and young McGahern would go with his father or other locals to catch them and other fish: "There was a family that went to school with me called the McMorrough. They were the last to fish the Boyle and the Shannon for a living. I never worked with them but actually knew how to fish for eel. I used to set eel lines myself. It was the sort of thing everybody did" (Collinge and Vernadakis 2003: p. 6). Despite their connection with survival skills and people's need to diversity their food, eels are connected in the Irish imaginary to the emergence of river Shannon on which Carrick-on-Shannon is placed, and an old legend retrieved and brought to life by Susie Minto mentions a huge ollphéist or serpent that made its way through rocky caverns and soft ground until it meets "a mighty gathering of enchanted eels, which it had to battle for its survival", then swallows a drunken piper sent after him, but, being heavily disturbed by the noise, it expels him until the piper returns to the water from which the monster appeared, vanishes mysteriously, being lured away: "It is said that one of the enchanted eels had survived and O'Rourke had fallen under its magic" (Minto 2013: p. 28).

What is transferred from the local communal imagination into McGahern's fiction in this case is the animal's ability to suggest sheer force, and its ambiguous status between a snake and a fish, bringing this feature into a wider context of transformation. "Korea" connects thus the transformational potential of the eel with the journey to adulthood implied by a young man's deception followed by revelation. The story shows that fishing was an activity taking place regularly for the son and father in the story, and the visual elements about eels support both the hint to boldness and liveliness, and back the accelerated pace of the story: "As the eels came in over the slide I cut them loose with a knife into a wire cage, where they slid over each other in their own oil, the twisted eel hook in their mouths" (McGahern 1992: p. 55). The symbolism of death and its transfer from beasts to humans expands when we learn about a shooting involving the father in a Mountjoy ambush in 1919 and the rememoration connects painful memories with the father's own immoral intentions of earning a substantial income by sending his son in America, even if he could have been killed in war.

In "The Stoat", first published in The Getting Through collection of stories in 1978 and Collected Stories in 1992, and later removed from Creatures of The Earth published in 2009, 
the writer uses the animal symbolism in a similar manner: animal killing working as a direct opening sustains the main topic of the story, with a subsequent meaning derived from the metaphor of stoat as victim transferred to human characters. The beginning of this short story reveals a young man golfing, he hears the high cry of a rabbit wounded by a stoat, and the short and accelerated image draws on the visual and oral narrative elements: the "crying high in the rough grass", "the clubs rattled", the rabbit sitting "rigidly still on a bare patch of a loose sand, crying" and the aggressor "slithering away like a snake into the long grass" (McGahern 1992: p. 152).

The story is soon directed to a widower in search of a partner, but the failure of this potential engagement with Ms McCabe is forewarned by the rapid gesture of the protagonist at the beginning: "I stilled it [the rabbit] with a single stroke." An almost identical fragment in Memoir hints to the memory of a real hunting day used by the novelist in this short story: "When I brought the wounded rabbit back, he killed it with a single stroke of his hand" (McGahern 1992: p. 106).

In her analysis of this piece, Danine Farquharson opens the fragment to a series of bilateral relationships: father-son, father-woman: "The narrator will variously depict the father as both rabbit and pathetic stoat, and Miss McCabe as both predator and prey" (2009: p. 7). On the other hand, the image of rabbit being killed by the stoat, and this incident casting a premonition on characters and events to be told appears in The Dark as well, with the famous opening of the story when the father turns into a violent aggressor to his own son; the image of the black leather belt suggests a similar predatory behaviour: "The belt twitched his trousers, an animal's tail" (McGahern 2008b: p. 8). Her interpretation is supported by the third paragraph, which is repeated at the end, and whose recurrence is meant to link the narration to the symbolic role of the three main characters:

All night the rabbit must have raced from warren to warren, the stoat on its tail. Plumper rabbits had crossed the stoat's path but it would not be deflected; it had marked down this one rabbit to kill. No matter how fast the rabbit raced, the stoat was still on its trail, and at last the rabbit sat down in terror and waited for the stoat to slither up and cut the vein behind the ear. I heard it crying as the stoat was drinking its blood (McGahern 1992: p. 152).

This symbolism is only enhanced by other narrative elements meant to suggest the human-animal similarities in terms of search and success/failure. The son's increasing incomprehension only adds to the strangeness of the story: "They seemed to have reached some vague, timid understanding that if the holiday went well they'd become engaged before they returned to their schools in September. At their age, or any age, I thought their formality strange, and I an even stranger chaperon." (McGahern 1992: p. 153) The son perceives a rather hesitant Ms McCabe in terms of appearance and behaviour; she has "a waif-like sense of decency - that was at once appealing and troubling" and acts "like a girl, in love with being in love a whole life long without ever settling on any single demanding presence until this late backward glance fell on my bereft but seeking father." (McGahern 1992: p. 155) None of the characters in this story succeeds in finding a comfortable and durable life role, their searches turn into unreal self-promises. To a clear 
extent, there is a higher gap from expectations and achievements and the father's growing inability to reflect upon his actions appears before the close: "I saw that my father had started to run like the poor rabbit. He would have been better off if he could have tried to understand something, even though it would get him off nothing. Miss McCabe was not alone in her situation" (McGahern 1992: p. 156-7).

"The Stoat" is actually quite close to what had happened to the McGaherns in the years following his mother's death, when the Sergeant tried to get married for a second time. The novelist describes shortly in Memoir the same incident, and the story preserves the very name of the school principal considered for the role of a stepmother. Although the novelist tries to relate the incident in a rather neutral tone, the tone of the narration includes an irony to his father's hypochondriac attitude when he learns that she had had a 'turn': "The effect was startling. Within an hour he had gathered up the pots and pans we'd brought, written a letter to Miss McCabe, and packed the whole family except myself into the small blue Ford" (McGahern 2005: p. 181). The chance of getting married to someone suspected of having a serious heart condition makes the sergeant forget an amiable and gentleman's posture and turn cowardly yet safely to a hurried retreat.

Other stories bring to life casual incidents related to old beliefs and folk superstitions: in "Swallows" a Sergeant seizes the broom from his maid "who stood stock-still in superstitious horror before the rocking shaving mirror," followed by her short comment "We'd have had seven years without a day's luck." (McGahern 1992: p. 204) In the spirit of Irish farce and satire, the title itself is used to look critically at failed ambitions and vocation fiascos: two men share their passion for music, but while the violinist has a clear taste for elite culture, his interlocutor and listener asks the first to play "Danny Boy", a popular tune, instead of classical pieces, leading the Surveyor to disappointment briefly revealed by "his irritated face above the old lovely violin" (McGahern 1992: p. 207).

\section{Images of children and adults}

Equally complex constructions, alternating between movement, sound, and visual elements instil confusion, alienation, disturbance or a diffuse yet pervading state of day-dreaming for many characters in his stories, sometimes an effect of psychological growth, or the ongoing impact of isolation and illness, as his nameless character in The Dark confesses repeatedly: "the days before the exam took on the quality of a dream" (McGahern 2008b: p. 138) or "one day she would come to me, a dream of flesh in woman" (McGahern 2008b: p. 30); "It was the University, you looked at it, the shambles of a dream" (McGahern 2008b: p. 186).

In The Barracks, family order rests on Elizabeth Reegan's shoulders, wife and adoptive mother of Reegan's children, spending her life between day chores and night rest. The writer employs in this case a narrative based on longer syntactic structures designed to suggest the alternation between stable to fluctuating moods:

"Her woman's days had no need of change. They were full and too busy, wanting nothing but to be loved. There was the shrill alarm clock at eight in the barracks morning and the raking of the ashes over the living coals close to midnight: between these two instances, as between tides, came the retreating nights of renewal and the chores of 
the days on which her strength was spent again, one always unfinished and two more eternally waiting, yet so colourless and small that only on a reel of film projected slowly could they be separated and named; and as no one noticed them they were never praised" (2009c: p. 21).

Although formally attached to Catholicism, in a daily and repetitive type of devotion, the world of the rural Ireland McGahern had grown in was a more mysterious and cryptic place than when looking at the surface. The way the novelist describes the influence of old pagan rites, and their persistence and influence on people's lives indicate this strong attachment to what must have been Celtic rituals hundreds of years before his birth:

"I had started to go to school with my mother, and my grandmother's dominion began to be eroded until I went down with whooping cough. She at once moved me into her own room, barring access to everybody; and when my mother pleaded that at least the doctor should be called in she refused, and sent instead into the mountains for a stallion. I remember being carried out in a pile of blankets, the sky darkblue and the night bright with the starts of a night of frost, a man holding the stallion by the bridle ring, and the stars in the clear sky as I was passed three times under the stallion in the name of the Father and Son and Holy Ghost, and my mother's tense face in the starlight as she said, 'I think we should send for the doctor now as well', my grandmother calmly handing the man silver coins ringing of iron as the stallion stamped in the cold" (McGahern 2009d: p. 48-9).

That is also reflected in short stories, for instance Luke Horan in "The Recruiting Officer", the fifth boy in a line of male children unbroken by girls is considered by his own family to get special powers: "while he wailed under the water of his baptism at the stone font in Coothall church a worm was placed into his hand - either the priest didn't see or was content to ignore it - but the Horans rejoiced, their fifth infant boy would grow up with the power of healing ringworm" (McGahern 1992: p. 107).

"Love of the World" is one of McGahern's few novellas, opening with a vision of a calm life. Kath Ruttledge, a young "dark beauty before our eyes" (McGahern 2009a: p. gets married to Guard Harkins, an established county footballer with Mayo. Despite his growing fame, the two lovers are careful to share their intention and get approval of her family: "These visits were always tense and delicate because they were at once a statement of intent and a plea for approval" (McGahern 2009a: p. 937).

The opening of the story is reflected by the end where two final questions hint to expected answers:

"It is very quiet here. Nothing much ever happens. We have learned to tell the cries of the birds and the animals, the wing-beats of the swans crossing the house, the noises of the different motors that batter about the roads. Not many people like this quiet" (2009a: p. 933).

"Wildfowl scattered from the reeds along the shore out towards the centre of the lake as soon as the car door opened. They squawked and shrieked for a while before turning into a dark silent huddle. Close by, a white moon rested on the water. The star in their places were clear and fixed. Who would want change since change will come without 
wanting? Who this night would not want to live?" (McGahern 2009a: p. 1026).

In her analysis devoted to this story, Louvel illuminates the understanding of "breaching", first noted in a previous draft McGahern read to her:

From a very young age he was drawn to older women: "Callaghan doesn't want the trouble of schooling them; he likes his breaching done" was joked to cover suspicion and resentment of any deviation. What pang of pleasure passing them might they be missing? They too would kill the wildfowl though they had no taste for the dark meat.

Then John McGahern started to explain what kind of work he had been doing. He had spent some time in the University Library to try and find a suitable word that would condense into one closely-knit phrase what he had previously developed at greater length. Thus he had come upon "breach" which articulated three terrains: that of horses, of agriculture and the earth, and of women. And of course "breach" entails a violent action of rupture, a disruption of order and of the law, which is what happens in the story. The polysemy of the word enabled McGahern to condense in one sentence the complex stakes of the story and the crucial role of Callaghan in the final disaster. (Louvel 2009: p. 2)

Louvel suggests that anticipation is enhanced in this story by the gripping bird-female metaphor; to her view we add a third interpretation suggesting the inevitable:5

a) it indicates the passage of time, irreversible actions, hopes and failures entailing story actors; "'Callahan's built a big cage without first finding a bird."“ (2009a: 1008); "A silence came round all that happened. Nobody complained about the normal quiet. Birds cries were sweet. The wing-beat of the swan crossing the house gave strength. The long light of day crossing the lake steeped us in privilege and mystery and infinite reflections that nobody wanted to break or question. Gradually the sense of quiet weakened" (McGahern 2009a: 1020). A similar image is echoed by the young erotic writer in The Pornographer: "Death must sometimes come the same way, the tension leaving the body, in pain and not in sweetness and pride, but a last time, the circle completed, never having to come back to catch the flying moment that was always the same, always on the wing" (McGahern 2009e: p. 57);

b) it hints to fearfulness and frailness: Kate is gentle, natural, trustful, but she gradually turns into an evasive, frightened prey. Before her end, she feels that something dramatic will happen, but although Callahan sees her "excited and troubled" (McGahern 2009a: 998), "As he [Callahan] got out, he disturbed wildfowl in the reeds along the shore, and they scattered, shrieking, towards the centre" (McGahern 2009a: 1015);

c) it is a bad omen deriving from Old Irish imagery: "Black birds (especially crows and ravens) were connected with inauspicious augury, especially when the birds cried from above; they were at times associated with the prophecy of death, associations that persist in Ireland to the present" (Tymoczko and Ireland 2003: 155). This is correlated with McCoys's findings that Brig, the mother-goddess, starts lamentation by shrieking (Tymoczko \& Ireland, 2003, p. 208); in the story, the birds cry, squeak and shriek, while Kate shares her own premonition about something going to happen (McGahern 2009a: p. 1001); or a clearer hint to tourists taken by Harkin in expeditions enjoying the "slaughter of the songbirds" (McGahern 2009a: p. 961). Frank Shovlin adds his own perspective, linking the bird motif to an aimed at ascension to heaven (2016: p. 158). 
Her father's death seen as an inevitable result, "James had married into the place and he cared for the fields more than if they were his own" (McGahern 2009a: p. 952) requires this phrase be decrypted as an "ancient textual representation of the chief as married to the land' huge impact on his family and the local community. It is partially his death which makes Kate more vulnerable to Harkin's violence; there is no man in her family to back her. The symbol of his land and family losing their head is beyond an ordinary death: "The loss of the land and the displacement of the chief was very early on encoded in the metaphor of widowhood as conveyed through elaborate tropes of lamentation" (Witoszek and Sheeran 1998: p. 38).

At the beginning, Harkin strikes her with his powerful presence, while at the end the former sportsman uses his power to strike her physically down for ever. Kate's love for the children draws her tragically to her former house, and the narrator shows her abruptly silenced figure: "As she turned her back she heard a sharp click but did not turn to see him lift the gun. One hand was reaching for the door when she fell, the other closed tight. When it was opened, it held a fistful of small black currants" (McGahern 2009a: p. 1014).

The title of the novella does not match with the series of violence acts displayed, and this is revealed in an articulated crescendo: first, a preliminary hint to "something violent and shocking" to happen; then, Kate who could "hardly breathe" until he gets well from an injury; the allegedly-invoked "tense and delicate" visit of the two lovers to Kate's parents (McGahern 2009a: p. 764); Harkin standing out "without blemish" in her eyes though she is "light, almost fearful with happiness" (McGahern 2009a: 765) as the visit goes well; and finally, the "silent, almost unbearable strain in the evening s with Harkin" (McGahern 2009a: p. 822) air and her father's premonition that she will not have an "easy life" (McGahern 2009a: p. 768).

\section{The otherworld: Funerals, premonitions and rites of passage}

Human and non-human characters in McGahern's stories have often dramatic events, sources of conflicts and alienation, and deal with despair and death in both rural and urban sites. In the routine of daily actions it is practically indecent to expose fears and talk about any kind of anxiety, yet the hold of apprehension on characters is long and painful. The flow of the characters' inner speech makes the reader sympathize with difficult intervals, isolation and trauma. Characters presented in McGahern's novels and stories are based on events taking place in the 1940s and the 1950s and 60s, yet their feelings, as well as the context behind their experiences are connected to the collective memories incorporating tales and rituals preserved in small communities across the countryside.

From immemorial times, the otherworld was a space beyond human touch, accessible only to spiritually-gifted individuals. The way the Irish looked at it indicates both an ideal and intangible space, suggested by Tymoczko as "the land of youth" or "the land of women" (2003: p. 180).

In "The Country Funeral", the story opens with two brothers engaged in an ordinary discussion: Fonsie and Philly Ryan, Philly coming home for his summer holiday as he works in the oil industry in Saudi Arabia and Bahrain. The two nephews and Peter McDermott, their uncle, have a feeling in common, and that is individual loneliness: 
Philly is aware that the quiet atmosphere of the bar "became too close an echo of the emptiness he felt all around his life" (McGahern 1992: p. 375), while the memory of their uncle reflects, among other elements, a recurrent reserve in carrying out a conversation between him and his three nephews (p. 380).

Fonsie, the wheelchair-bound brother, Philly and John, the third of them, leave together for their uncle's funeral after his sudden death. However, their memories of him are not enjoyable ones: "I always felt if he got the chance hed have put me in bag with a stone and thrown me in a bog hole like that black whippet" says Fonsie (McGahern 1992: 381-2), "It's terrible when you're young to come into a place where you know you're not wanted." John said (McGahern 1992: p. 381).

Several passages describe elements included in the Irish wake tradition: clocks are stopped to run, the body's hands are crossed and placed to hold praying beads; the family buys food and drinks for visitors, and the night before the funeral a wake or vigil is organized, when relatives and neighbours pay their respect and talk about the dead one. The tradition is, therefore, "a historical process: it has been transmitted and transformed by means of the dialogic imagination from generation to generation. Funerary texts recreate a culture in which the initiation into the process of modernity has been interminably protracted and perforce turned into a way of life. They write Ireland as a liminal zone, a pier into the modern world" (Witoszek and Sheeran 1998: p. 12).

However, multiple elements in this story work along or against community tradition: the clocks still work when the three brothers arrive; despite their uncle's modest life, the three brothers decide to order a sumptuous coffin and hearse: "Peter never behaved like a small man when he went out" says Jim Cullen, his neighbour; "The McDermotts were always big people" (McGahern 1992: p. 384); "All through the evening and night people kept coming to the house while other who had come earlier quietly left. First they shook hands with the three brothers, then went to the upper room, knelt by the bed; and when they rose they touched the dead hands or forehead in a gesture of leavetaking or communion, and then sat on one of the chairs by the bed" (McGahern 1992: p. 391).

The narration mixes with humorous lines: "By morning [cigarette] butts would be seen floating in the bottoms of several of the bottles like trapped wasps" (McGahern 1992: p. 391); or sharper ironic ones: "Everything was gathered into the rushing complaint: the poor key with the string, keeling over in the potato stalks, the bloody wallet, the beads in the huge hands that he always felt wanted to choke him, the bit of cotton sticking out of the corner of the dead man's mouth" (McGahern 1992: p. 385) ; “...I do not think Gloria Bog is ever likely to become the Costa Brava” says Philly (McGahern 1992: p. 399).

There are several references to Peter's hands, an iconic element for his hard life and tough behaviour, noted as "enormous on the white sheet" or "clasped together on the sheet" (McGahern 1992: p. 383). His best neighbour, Jim Cullen, the one in charge with funeral preparation before the arrivals of the three brothers, shares this physical feature: "They noticed how large the old farmer's hands were as they gripped Philly by the wrist and pushed the hand and notes down into his jacket pocket, refusing stubbornly to accept any money" (McGahern 1992: p. 402). Large hands emerge as a visual metaphor of one's earthiness in other stories too, for example in Amongst Women: "While he spoke his 
enormous hand encircled his sherry glass as if it were a stalk of grass" (2008a: p. 154) or the encounter between James Murphy and Kate Ruttledge in That They May Face the Rising Sun: "He held out an enormous hand. She pretended to be afraid to trust her hand to such strength" (2002: p. 7-8).

The demarcation between the space where neighbours pay their respect and the space where they get together is that of two separate worlds, one on earth, the other for the dead, and where everybody's conversation regards Peter's life, struggles and merits: "Almost all the talk was of the dead man. Much of it was in the form of stories. All of them showed the dead man winning out in life and the few times he had been forced to concede defeat it had been with stubbornness or wit" (McGahern 1992: p. 391); "In the upper room there was silence, the people there keeping vigil by the body where it lay in the stillness and awe of the last change; while in the lower room that life was being resurrected with more vividness than it could ever have had in the long days and years it had been given" (McGahern 1992: p. 392). His skill to produce animal figures out of shaped and glued matches is equally praised.

The wake had a complex function in Irish funeral tradition, and was fundamentally meant to:

"...alleviate the pain of bereavement by means of a riotous feast but also to "bribe" the spirit of the dead person, to keep him/her quiet and safely out of the living. (. . .) Apart from its countercultural dimension, the wake functioned as a theatre of social rehabilitation in which useless praise was on those who were denied a good word during life. The wake had the power to transmute, to bring the dead person out of anonymity, disgrace even, and transform him/her into a local legend" (Witoszek and Sheeran 1998: p. 27-8).

John is the only one staying overnight in their uncle's house, and once he counts the huge amount collected by the deceased, he reflects on Peter's life, as any human life:

"He thought of Peter sitting alone here at night making the shapes of the animals out of matchsticks, of those same hands now in a coffin before the high altar of Cootehall church. Tomorrow hed lie in the earth of the top of Killeelan Hill. A man is born. He dies. Where he himself stood now on the path between those two points could not be known. He felt as much as the child that came each summer years ago to this bog from the city as the rough unfinished man he knew himself to be in the eyes of the others, but feelings had nothing to do with it. He must be already well out past halfway" (McGahern 1992: p. 396).

Cars and mourners follow silently the coffin, but the road up the hill makes it a difficult task while the image of the landscape reverberates the meaning of this ceremony:

"The coffin went up and up the steep hill, sometimes swaying dangerously, and then anxious hands of the immediate followers would go up against the back of the coffin. The shadow of the clouds swept continually over the green hill and brown varnish of the coffin. Away on the bog they were a darker, deeper shadow as the clouds travelled swiftly over the pale sedge" (p. 400).

The symbolism of the coffin being rescued from falling on the hill is explained plainly by Fanny Bergen in her examination of this passage: "It is counted an ill-omen to stumble in a graveyard, or to fall from a car at a funeral. It is said that the last person in any 
churchyard will have to draw water for all the others there sleeping, until there is another burial" (1895: p. 20).

The memories of the funeral are as diverse as the characters involved in this story, and Philly is the only brother able to perceive the wholeness of the bog - indicating an appreciation of nature and humans in an almost pure world:

"I'll never forget it all the days of my life, the people coming to the house all through the night. The rows and rows of people at the removal passing by us in the front seat of the church grasping our hands. Coming in that small lane behind the hearse; then carrying Peter up that hill.' (... ) 'I felt something I never felt when we left the coffin on the edge of the grave. A rabbit hopped out of the briars a few yards off. He sat there and looked at us as if he didn't know what was going on before he bolted off. You could see the bog and all the shut houses next to Peter's below. There wasn't even a wisp of smoke coming from any of the houses. Everybody gathered around, and the priest started to speak of the dead and the Mystery and the Resurrection"' (McGahern 1992: p. 405).

The story brings the brothers closer to their roots, as a final opportunity to reflect on their life and change it, if needed, and represents a shift from 19th century practice, when the Roman Catholic Church worked hardly, often abusively, to eliminate the so-called "appalling practice" of wild wakes and lewd games against Christian practice:

"In this historic transformation of rural Irish religion, the central position of church and clergy could be considerably deified by "capturing" death, not only through suppressing the wild wake and the sexual release associated with it, but through recontextualizing death as a church centered experience, and mediating the experience with its own rituals, discourse and objects.

In terms of ritual, there was a considerable elaboration of funeral customs and emphasis on the significance of purgatory and hence masses for the dead - as had been done centuries earlier elsewhere in Europe. The wake remained a very significant household ritual and one still primarily in control of family and local community, with the clergy playing only a relatively minor role in the proceedings..." (Taylor 1989: p. 180).

It is not only one's death seen as a symbolic loss for the family, but also funeral details make the spiritual reconnection possible for the deceased; for instance when Johnny returns for his annual visit from England, and has a fatal heart failure. At his burial, the undertakers realize that they were about to position the deceased incorrectly, and they amend it shortly. Their conversation explains the title of the volume and takes old, immemorial rituals as being preserved into contemporary practice, but that is itself an issue under a question mark with old-fashioned communities captured by McGahern in fiction before turning extinct by the late twentieth century:

"Does it make a great difference that his head lies in the west?'

'It makes every difference, lad, or it makes no difference.' 'In

what way?' (...)

'He sleeps with his head in the west... so that when he wakes he may face the rising sun. Looking from face to face and drawing himself to his full height, Patrick Ryan stretched his arm dramatically towards the east. "We look to the resurrection of the dead"' (McGahern 2002: 281). 
A brief survey of the vocabulary shows it closely linked to recurrent symbols: the wheel, standing for the never-ending cycle of life and death taking place in a family or community, as illustrated by the story in the "Wheels" or the cyclicity present in the symmetric beginnings and endings: "The wheel of the summer turned pleasantly" (McGahern 1985: p. 43); "Like spinning a coin or wheel l'd let the number of the bus decide that evening" (McGahern 1979: p. 20). Wheels, in the studies on cultural archetypes and Self, annihilate the destructive power of time and take characters into immemorial space, where there is no sorrow or pain, because the mythical space they imply lacks a certain beginning or close: "The basic archetypal image of this creatively transformed reality of the world is the self-containing rolling wheel of eternity, every single point of which is a "turning point," that "often concludes with beginning and starts with the end".

Secondly, the water is suggested by multiple semantic alternatives: the sea, or the use of water by priests, but also hints to gulls, shells, fish etc.; the river is a powerful metaphor for life, change, growing or dying relationships, as revealed in a brief dialogue between Katie McManus, former family maid, whom McGahern calls "our last human link with the Aughawillan farm" (McGahern 2005: p. 267). The conversation between Katie and the novelist revolves around the lives of his sisters and brother, and then, the dialogue closes gently in a contemplative tone:

"She did not seem surprised when I told her that I had been married and divorced and had remarried. "I was certain you'd become a priest. If I'd have sworn anything I'd have sworn that," Katie said.

'The pull of life was too great,' I said. 'I always wanted to go on the river.'

'I wonder sometimes if there's all that much to it,' Katie said. 'It goes by', we all agreed" (p. 270).

Other key concepts include the light - as opposing the dark - symbol of knowledge, of spiritual peace, of getting meaning out of one's life. The dark side of the father-figures perceived by his seven children and his second wife has multiple fictional representations: "Her life was bound up completely with this man she so loved and whose darkness she feared" (McGahern 2008a: p. 60), adding up to the semantic area discussed earlier about violence and fear described in The Dark or numerous passages describing the writer's early appetite for reading, love for books and intellectual work. In "The Conversion of William Kirkwood", Sergeant McLoughlin criticizes Captain Kirkwood for deciding to change his belief since this implies, in the eyes of any Catholic, the rejection of the faith of his predecessors; but the captain replies firmly indicating that there is always an opportunity to search for what he calls a new type of light: "'Still, it must be no joke turning your back on your own crowd, more or less saying that they were wrong all those centuries," the Sergeant said. "No. Not if one is convinced of the truth," William pushed his glass away and rose. "They lived according to their light. It is our day now" (McGahern 1985: p. 128). A wide semantic inventory has been produced by Beatrix Busse et al. in her study including a linguistic and narrative analysis of some of his short stories.

In McGahern's magically- and realistically-built universe, the visual is the primary source of sensorial suggestions, covering a multitude of elements: colours, movements, stillness, cyclicity, and complementing the moods of the fictional personae. A brief analysis 
of the colour symbolism and the adjectives employed by the narrator to achieve different aims shows that McGahern targets both simple and complex constructions and effects:

1. White - standing for purity, innocence or frankness: " $\nabla \mathrm{We}$ won't have a white wedding," she said. " $\square$ White is to signify virginity and I'm hardly a virgin"” (McGahern 1979: p. 99); "When I set out to write By the Lake [the name for the U.S. version of Memoir], my ambition was to write about ordinary life, the kind of life that ordinarily "writes white" (Lee 2004: 1); "scattered white cottages" (McGahern 2009b: p. 32); "the fish showing its "vicious teeth and whiteness" (McGahern 2008b: p. 13); his mother's "white dress dropped away from her throat" (McGahern 2008b: p. 33); young Mahoney "washed as clean as snow" (McGahern 2008b: p. 43) after confession; "a white clover at your feet swayed under the clambering of a sucking bee" (McGahern 2008b: p. 85); "[the] soft white of the breast" (McGahern 2008b: p. 118); "Patrick Ryan stood between the narrow high banks of the lane exactly as he had appeared in the doorway on the night of the wake, the white shirt and face and silver hair glowing" (McGahern 2002: p. 296); "All my father's silver buttons and stripes and badges were shining as if it were a court day" (McGahern 2005: p. 125); "The floor was incredibly worn but it had taken on the soft glowing white of endlessly scrubbed deal" (McGahern 2008a: p. 172);

2. Black - a hint to authority, harshness and inflexibility/stillness: "I remember him [Sergeant Francis McGahern] most of all arriving out of wet dark night, his black cycling cape and pull-ups and black sou'wester hat shining with rain" (McGahern 2005: p. 69); "The black cat with the white paws sat high on the back of an armchair" (McGahern 2002: p. 206); "...would the black leather cut across his flesh this time, it was horrible and worse than death to think" (McGahern 2008b: p. 9); "the leather exploded on the black armrest beside where his year was" (McGahern 2008b: 10); "the black cat sat as studious as a scholar amid all the spawn and stirring of the pool as she waited to scoop up with one paw any amorous frog that rose too close to the rock" (McGahern 2002: p. 238);

3. Red - suggesting anxiety, fury or liveliness: young Mahoney's "face still red and heated" (McGahern 2008b: p. 10); "his lids lit up like blood-soaked curtains" (McGahern 2008b: p. 18); "the two men kill fleas turning into "a red speck of skin and blood crushed on the nail" (McGahern 2008b: p. 22); "you'd always hanker after it, it was the red rose of life" (McGahern 2008b: p. 84);

4. Brown, - often suggesting earthiness and matter-like consistency: "A mangled sheet of iron hung from an iron post like a dispiritted brown flag" (McGahern 2002: p. 202);

5. Blue - implying transparency, openness or characters' potential for change: "The old blue alarm clock was dancing on the table" (McGahern 2002: p. 204); "when it was filled, the blue stone was set to steep in a bag hung from the broken handle of a spade, and once it had melted and soda was added, the blue turned a rich turquoise" (McGahern 2005: p. 85);

6. Green - indicating the vibrant fields and old, natural pace of life: "the rich green of the grass in the shelter of the hedges travelled out over the whole fields" (McGahern 2002: p. 249);

7. Multiple colours - to show liveliness and/or mark a contrast: "the black bee unsteady and awkward on the ruffled whiteness" and "More [bees] were moving between the red and white and yellow heads [of flowers] in the sunshine" (McGahern 2008b: p.85); 
"The hard burnt colour of the freshly cut meadows softened and there was a blue tinge in the first growth of aftergrass that shone under the running winds" (McGahern 2002: p. 149); "a white mist obscured the dark green shapes of the beech trees along the head of the meadows and their sandals made green splashes through the cobwebbed pastures" (McGahern 2008a: p. 160).

The use of animal, vegetal and human representations is finely complemented by narrative operators linking nature and traditional folk imagery to ancient narratives, the writer switching from mild irony to parody, farce or sarcasm in indirect speech or conversations carried by the locals: "The talk is that old Joe himself will have to go to England this winter to pay off the expense of the funeral" (McGahern 1992: p. 149) and "Sticking your heels in, as usual" p. (331).

\section{Conclusions}

All major Irish writers find their vigour in the abundant folklore of their communities, and McGahern continues to bring to surface a diverse imagery, extracting diverse key symbols and motifs, such as trees or animals, and taking them forward into fiction. $\mathrm{He}$ also develops a certain line of the Irish literary, that of turning reality into a dream and vice versa, and this often makes protagonists pull all their strength to rebalance and redefine identity. Animals and trees are intricately and provocatively included in the human world, enhancing or diluting events and attitudes; death is not a far, distant, untouchable otherworld, but a space close to the living, though the locals sometimes need to confront it openly and do not close up the door to their rich past. Iconic images in stories implying death and mourning are the wake, public discourses about the deceased, and an almost comic mixture of respect, pragmatism and slipups. In his fictional world, space and time are elastic and re-connect to old traditions in both in a voluntary and involuntary way, combining newly created figures with characters taken from a close or remote past: victims and heroes, or poets and seekers of truth, in a display of selfishness and altruism. The line between comic and tragedy is thin, and animal or vegetal representations work occasionally as conventional helpers, or as obstacles in the (difficult) march of the hero along cyclical departures or returns.

The interdependence of literature and folklore re-emerges forcefully with each story, but narrative purpose and techniques vary, as the narrator switches from realism to irony or satire, while employing devices taken from vast bodies of folk and local tales, proving the endless capacity of Irish fiction to recycle images from familiar, local sources.

\section{Endnotes}

1 "Little Gidding", in Collected poems 1909-1962, New York: Hartcourt Brace and Company 1963, 206-207

2 Terms associated with the ranks of Celtic poets, the highest being the ollamh: in Kenneth L. Campbell, Ireland's History: Prehistory to the present, London \& New York: Bloomsbury Academic, 2014, 72; Rolland Green (ed.-in-chief), The Princeton encyclopedia of poetry and opetics, Princeton and Oxford: Princeton University Press, 2012: 121 
3 Hugh MacDiarmid, 'The Little White Rose', in Complete poems: Volume I, ed. by Michael Grieve and W. R. Aitken (Manchester: Carcanet, 1993), p.461

4 Scott Lyall, "Hugh MacDiarmid and the British State, The Bottle Imp, Issue 18, 2015 ezine

5 See Sharon Paice McLeod's comment on a passage from an eighth-century manuscript: 'Finn Mac Cumhall encounters a man sitting in a top of tree with a blackbird on his right shoulder. He held a vessel of white bronze in his left hand, in which there was a trout and some water. A stag stood at the foot of the tree. The mysterious figure in the tree was cracking open hazelnuts, symbolic of divine wisdom. He gave half of the nut to the blackbird and ate the other half himself. From inside the bronze vessel he took an apple, symbolizing passages between the worlds, again giving half to the stag and eating the other half himself. He then drank a sip from the vessel so that he, the trout, the stage and the blackbird all drank together. The blackbird may symbolize the Upper World, the stag the Middle World and the trout the Lo-wer World.' (67); also the mention of St Kevin's representations of holding a blackbird in his outstretched hand in Brendan Lehane's Early Christian Christianity, London and New York: Continuum, 2005 (66); or a poem about the death of a blackbird by Séamus Dall Mac Cuarta where 'aol', the Irish word for lime is a hint to purity and innocence, interpretation suggested by Eileen Kato in "For the Birds": 132-133

6 Erich Neumann, Art and the Creative Unconscious: Four Essays, London: Routledge and Kegan Paul, 1959: 203

\section{Bibliography}

Bergen, F. (1895) Burial and holiday customs and beliefs of the Irish peasantry. The Journal of American Folklore, 19-25.

Carassi, V. (2012) The Irish fairy tale: A narrative tradition from the Middle Ages to Yates and Stephens. (K. Wren, Trans.) Lanham, Maryland: John Cabot University Press.

Cardin, B. (2009) Absence does not cast a shadow: Yeats's Shadowy presence in McGahern's The wine breadth'. Journal of the Short Story in English, 2-11.

Collinge, L. \& Vernadakis, E. (2003) John McGahern - b. 1934. Journal of the Short Story in English(41). Retrieved May 15, 2013

Evans, E. E. (2000) Irish folk ways. Mineola, New York: Dover.

Farquharson, D. (2009) Violence and ontological doubt in \The Stoat'. Journal of the Short Story in English (53) Retrieved from http://jsse.revues.org/1009

Harris, J. (2008) Folklore and the fantastic in nineteenth-century British fiction. Aldershot and Burlington: Ashgate.

Lee, H. (2004, April 7) Readings and conversations: John McGahern. Retrieved May 10, 2013, from www.lannan.org: http://www.lannan.org/images/lit/john-mcgahern-040407-transconv.pdf

Louvel, L. (2009) Reading John McGahern's Love of the world' a fistful of images. Journal of the Short Story in English (53). Retrieved October 10, 2013, from http://jsse.revues. org/997 McGahern, J. (1985) High ground and other stories. London: Faber and Faber.

McGahern, J. (1992) The collected stories. London: Faber and Faber. 
McGahern, J. (2002) That they may face the rising sun. London: Faber and Faber.

McGahern, J. (2005) Memoir. London: Faber and Faber.

McGahern, J. (2008a (1991)) Amongst women. London: Faber and Faber.

McGahern, J. (2008b) The Dark. London: Faber and Faber.

McGahern, J. (2009a) Creatures of the earth. (ebook). London: Faber and faber. Retrieved April 10, 2013, from iTunes

McGahern, J. (2009a) Preface. In Creatures of the earth: New and Selected Stories. London: Faber and Faber.

McGahern, J. (2009b) Love of the world: Essays. London: Faber and Faber Ltd.

McGahern, J. (2009c) The Barracks. London: Faber and Faber.

McGahern, J. (2009d) The Leavetaking. London: Faber and Faber.

McGahern, J. (2009e) The Pornographer. London: Faber and Faber.

Minto, S. (2013) Leitrim folk tales. Dublin: The History Press Ireland.

O Giollain, D. (2000) Locating Irish folklore. University College Cork: Cork University.

Quintelli-Neary, M. (1997) Folklore and the fantastic in twelve modern Irish novels.

Westport, Conneticut and London: Greenwood.

Sharpe Freeman, E. (1988) Dream Analysis. London: Karnac.

Taylor, L. J. (1989) Bas In Eirinn: Cultural constructions of death in Ireland. Anthropology Quarterly, 4(62), 175-187.

Tsukamoto, K., \& Kuroki, M. (2014) Eels and humans. (K. Tsukamoto, \& M. Kuroki, Eds.)

Tokyo, Heidelberg: Springer.

Tymoczko, M., \& Ireland, C. (Eds.). (2003) Language and tradition in Ireland: Continuities and displacements. Amherst and Boston: University of Massachusetts.

Witoszek, N., \& Sheeran, P. (1998) Talking to the dead: A study of Irish funerary traditions. Amsterdam-Atlanta, GA: Rodopi. 